\title{
ANALYSIS OF THE IMPACT OF WEATHER CONDITIONS ON THE EFFECTIVENESS OF OIL SPILL RECOVERY OPERATION IN SIMULATED CONDITIONS (PISCES II)
}

\begin{abstract}
The ability to use computer simulation to predict the behavior of oil spills at sea enables better use of available personnel and resources to combat such spills. The use of oil collecting equipment properly selected to suit the conditions is essential for the operation to be effective. Therefore, an attempt is made to verify the influence of weather conditions on the efficiency of oil recovery. Three types of spilled crude oil were simulated. A relevant experiment was conducted on a PISCES II oil spill simulator.
\end{abstract}

\section{Keywords:}

oil spill simulation, oil pollution characteristics, hydrometeorological conditions, oil pollution behavior.

\section{INTRODUCTION}

Crude oil is a mixture of many compounds, and its composition depends on the conditions of its formation, especially the time and place in which it evolved. Oil in the state called crude is a mixture of many chemical compounds of which the most important are hydrocarbons and compounds containing mainly carbon and hydrogen, as well as atoms of sulfur, oxygen, nitrogen, or all of these together. Crude oil that has been spilled in the sea is subject to physical and chemical processes, and their intensity depends on the type of oil, as well as meteorological conditions [Fabisiak, 2008]. The most important of these processes are: dissolution 
in water, evaporation, dispersion, adsorption, sedimentation of heavy fractions, oxidation, and microbial degradation. These processes have a significant impact on the distribution of residual oil in the marine environment. Once some oil is spilled, it begins to spread on the sea surface. The direction and speed of oil slick movement depend mainly on the temperature, wind direction and currents. Parallel to spreading, evaporation of volatile oil components may last up to a few weeks [Fabisiak, 2008].

Pollution of the seas by oil is constantly increasing and in recent years has become a problem all around the world. Oil spills threaten human health, contaminate drinking water, devastate natural resources and disrupt the economy. Every effort must be taken to prevent spills, oil leaks and to effectively remove them once they occurred. The best solution is a highly coordinated oil clearance operation, if response measures have been planned in advance and properly deployed.

A key element to combat oil spills is careful selection and proper use of equipment and materials most suitable for the type of oil and the conditions at the site of oil spill [Łazuga, Górtowski, 2011]. The sea state and the weather at the scene are equally crucial, as meteorological conditions affect the behavior of spilled oil and determine the effectiveness of response techniques [Kassabi, 2010].

An early as 1998 Shoier analyzed the use of a belt skimmer both experimentally and theoretically. The results of the study showed that oil recovery rate increased in proportion to the speed of the belt and oil layer thickness. Khalil and Hammond [2000] conducted an experiment to test the ability of the belt skimmer to recover oil depending on various operating parameters. The results of their study showed that the rate of oil recovery increases with increasing thickness of the spilled oil layer and greater immersion of the belt. The inclination angle of the belt turned out important as the maximum amount of collected oil was obtained at the lowest possible angle of the belt used in the experiment.

Skimmers are the cheapest and most effective devices to remove spilled oil from water surface. Their efficiency is high and the level of collecting oil is outstanding. Skimmers are easy to assemble.

The recovery element of a skimmer diverts or skims the oil from the sea surface, where it flows to the inlet side of a pumping system for transfer to storage. The mechanisms through which the oil is removed from the water surface include the oleophilic systems relying on adhesion of oil to a moving surface, suction systems, weir systems relying on gravity, and systems which physically lift the oil with mechanical oil scoops, belts or grabs [ITOPF 2012]. 
Oleophilic skimmers utilize materials that have an affinity for oil in preference to water. The oil adheres to the surface of the material, which rotates and extracts the oil from the water surface. They are most effective for the oil of medium viscosity ranging from 100 to 2000 cSt [ITOPF 2012].

\section{EXPERIMENT ASSUMPTIONS}

Simulations were performed on an oil spill simulator PISCES II [Manual (version 2.93), Transas Ltd., 2008].

The simulator allows conducting simulations of removing the spill using available resources for combating oil pollution at sea and possible interactions of pollutants with the coast. Meteorological conditions that can be simulated include air and water temperatures, wind direction and speed, sea state, parameters of currents. All of these parameters can be dynamically modelled during the simulation. The simulation results can be recorded and then analyzed.

During the simulation of oil clearance operation, the system for collecting spilled oil had the parameters shown in Table 1.

Tab. 1. The parameters of oil collecting equipment

[PISCES II Manual (ver. 2.93), Transas Ltd., 2008]

\begin{tabular}{|l|l|l|l|l|l|}
\hline \multicolumn{2}{|c|}{ Model data skimmer } & \multicolumn{2}{c|}{ Model data boom open water } & \multicolumn{2}{c|}{ VOSS } \\
\hline $\begin{array}{l}\text { storage } \\
\text { capacity }\end{array}$ & $30 \mathrm{~m}^{3}$ & height & $0.6 \mathrm{~m}$ & beam & 5 \\
\hline recovery rate & $50 \mathrm{~kg} / \mathrm{sec}$ & depth & $1.1 \mathrm{~m}$ & crew & 2 \\
\hline $\begin{array}{l}\text { additional } \\
\text { water }\end{array}$ & 0 & slack & $5 \%$ & $\begin{array}{l}\text { cruising } \\
\text { speed }\end{array}$ & 250 \\
\hline skimmer type & belt & length & $1000 \mathrm{~m}$ & deadweight & 80 \\
\hline efficiency & factor & capacity & $0 \mathrm{~m}^{2}$ & draft & 1 \\
\hline sea factor & $\begin{array}{l}0.01 .0 ; 0.6 \\
0.1 ; 1.30 .5\end{array}$ & $\begin{array}{l}\text { deployment } \\
\text { speed }\end{array}$ & $0.3 \mathrm{~km} / \mathrm{h}$ & LOA & 20 \\
\hline $\begin{array}{l}\text { viscosity } \\
\text { factor }\end{array}$ & $\begin{array}{l}0.00 .0 ; \\
1000.00 .2 ;\end{array}$ & retrieval speed & $0.6 \mathrm{~km} / \mathrm{h}$ & range & $200 \mathrm{Nm}$ \\
\hline $\begin{array}{l}\text { recovery } \\
\text { radius }\end{array}$ & $20 \mathrm{~m}$ & efficiency & 1 & max speed & $1.9 \mathrm{kts}$ \\
\hline max speed & $1.9 \mathrm{kts}$ & sea factor & $\begin{array}{l}1.51 .0 ; 1.6 \\
0.9 ; 1.70 .8\end{array}$ & & \\
\hline & & velocity factor & $\begin{array}{l}0.31 .0 ; 0.5 \\
0.9 ; 0.60 .8\end{array}$ & & \\
\hline & & max speed & $1.9 \mathrm{kts}$ & & \\
\hline
\end{tabular}


During the experiment, the behaviour of three grades of oil was examined in certain weather conditions: light - Bent Horn, Arabian medium and Belridge heavy. The characteristics of these fuels is presented in Table 2.

Tab. 2. Characteristics of the types of oil used in the experiment [PISCES II Manual (ver. 2.93), Transas Ltd., 2008]

\begin{tabular}{|l|l|l|l|}
\hline \multicolumn{1}{|c|}{ Fuel characteristic } & \multicolumn{1}{c|}{ Bent Horn } & Arabian medium & \multicolumn{1}{c|}{ Belridge heavy } \\
\hline group & II & III & IV \\
\hline density & $41.3[\mathrm{API}]$ & $27.4[\mathrm{API}]$ & $13.6[\mathrm{API}]$ \\
\hline surface tension & $53.5[\mathrm{dyne} / \mathrm{cm}]$ & $20[\mathrm{dyne} / \mathrm{cm}]$ & $20[\mathrm{dyne} / \mathrm{cm}]$ \\
\hline viscosity & $29.3[\mathrm{cSt}]$ & $271[\mathrm{cSt}]$ & $12931[\mathrm{cSt}]$ \\
\hline maximum content of water & $70 \%$ & $70 \%$ & $70 \%$ \\
\hline emulsification constant & $0 \%$ & $0 \%$ & $0 \%$ \\
\hline pour point & $-18\left[{ }^{\circ} \mathrm{C}\right]$ & $-28\left[{ }^{\circ} \mathrm{C}\right]$ & $2\left[{ }^{\circ} \mathrm{C}\right]$ \\
\hline flashing point & $-9\left[{ }^{\circ} \mathrm{C}\right]$ & $36\left[{ }^{\circ} \mathrm{C}\right]$ & $90\left[{ }^{\circ} \mathrm{C}\right]$ \\
\hline
\end{tabular}

The experiment was carried out by simulating the spillage of 1.000 tons of oil under constant weather conditions, and the variable was wave height of respectively 0,1 and $2 \mathrm{~m}$.

Spill was simulated in the same position at sea for each simulation. The oil collecting unit was moving along a fixed route by making a single passage through the oil slick. For each oil grade three simulations were made (total of 9 simulation variants).

\section{THE RESULTS OF OIL RECOVERY SIMULATIONS}

Below are the results obtained during the simulation of oil spill and its recovery operation in three weather variants:

- variant 1 - wave height $=0 \mathrm{~m}$;

- variant 2 - wave height $=1 \mathrm{~m}$;

- variant 3 - wave height $=2 \mathrm{~m}$.

For each weather variant the simulated spilling involved one of three types of fuel. The results are shown graphically as the amount of collected fuel, depending on simulation time. The simulation records included performance factors of oil-collecting device. 


\section{Simulation 1 - wave height 0 m}

The simulations were performed in a single passage of the device through the oil slick. Spill data recordings were performed automatically every minute.

The efficiency factor in such weather conditions was:

- for light crude oil - 0.003;

- for medium crude oil - $0.026-0.024$;

- for heavy crude oil $-0.569-0.571$.

Figure 1 presents the amount of collected oil for the above efficiency factors.

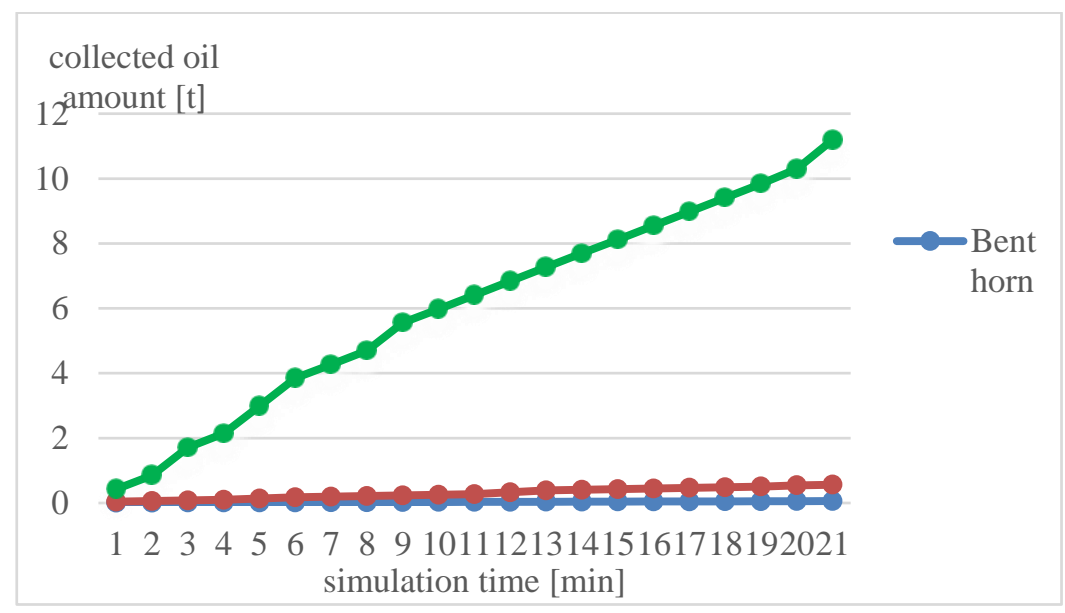

Fig. 1. The amount of oil collected in a single passage at a wave height $0 \mathrm{~m}$

The chart shows that the collection of heavy oil using belt skimmers is more effective than skimming light oil that is excessively dispersed, which makes effective collection difficult.

\section{Simulation 2 - wave height of $1 \mathrm{~m}$}

The simulations were performed in a single passage of the skimmer through the oil slick. Spill data recordings were performed automatically every minute.

The efficiency factor in such weather conditions was:

- for light crude oil - 0.002;

- for medium crude oil - 0.018 ;

- for heavy crude oil -0.407 . 
Figure 2 presents the amount of collected oil for the above efficiency factors.

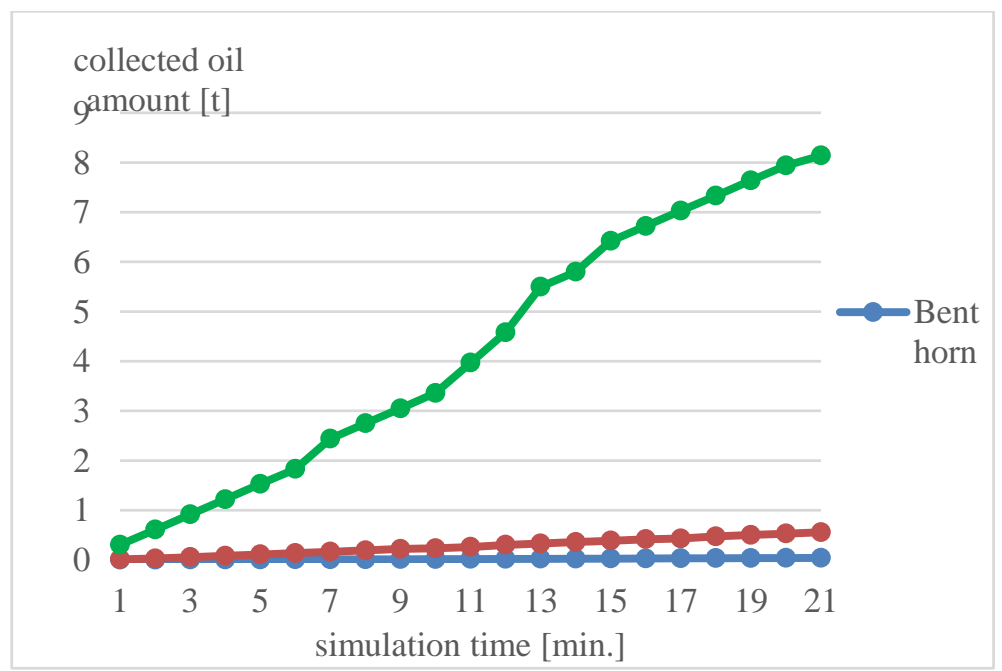

Fig. 2. The amount of oil collected in a single passage at a wave height $1 \mathrm{~m}$

Like in the first simulation, heavy oil also had a higher efficiency factor, which translated into the amount of collected oil in a single passage through the oil slick in constant weather conditions.

\section{Simulation 3 - wave height of $2 \mathrm{~m}$}

In simulations with a wave height of $2 \mathrm{~m}$, the oil collection efficiency factor was 0 for each type of oil, which means that with wave heights greater than $2 \mathrm{~m}$ spilled oil is not removed. Therefore, the impact of meteorological conditions (wave height in this case) on the effectiveness of spill clearance is essential.

\section{ANALYSIS OF THE EFFICIENCY FACTOR IN SIMULATED OPERATIONS}

The efficiency factor depends on the type of skimmer used for oil recovery and type of oil spilled. The experiment made use of a belt skimmer, and the efficiency of the skimmer is shown in Figure 3. 
The experiment has shown that light oil was characterized by the lowest rate in effective recovery of oil, while the recovery of heavy oil resulted in the largest amount of recovered spill under the same weather conditions. Light oil is subject to dispersion to a substantial extent, forming a fine film on the surface, which reduces its effective recovery. Heavy oil creates a thick layer on the water surface, its dispersion is smaller, which facilitates its effective collection.

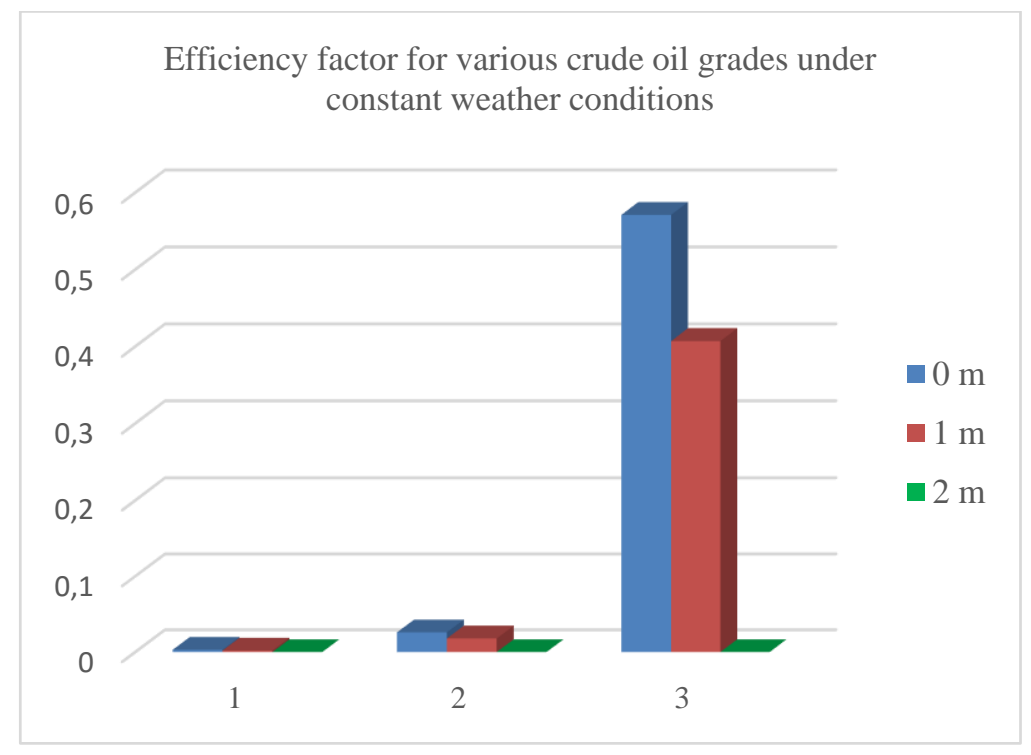

Fig. 3. Oil recovery efficiency factor for three oil types: 1) Bent horn;

2) Arabian medium; 3) Belridge heavy under constant weather conditions

\section{ANALYSIS OF THE IMPACT OF THE SEA STATE ON THE EFFICIENCY OF OIL RECOVERY OPERATIONS}

The above presented simulation results show that oil density, viscosity and wave height have the greatest impact on the amount of collected oil.

In the case of light crude oil (Bent Horn) the observed efficiency factor was low, only 0.003 and 0.002 for wave heights, respectively, $0 \mathrm{~m}$ and $1 \mathrm{~m}$, which resulted in a very small amount of recovered oil: only $0.058 \mathrm{t}$ and $0.04 \mathrm{t}$ in a single passage through an oil slick. The following graph shows that the wave height was important in the experiment, as in two metre waves the oil recovery operation was ineffective. 


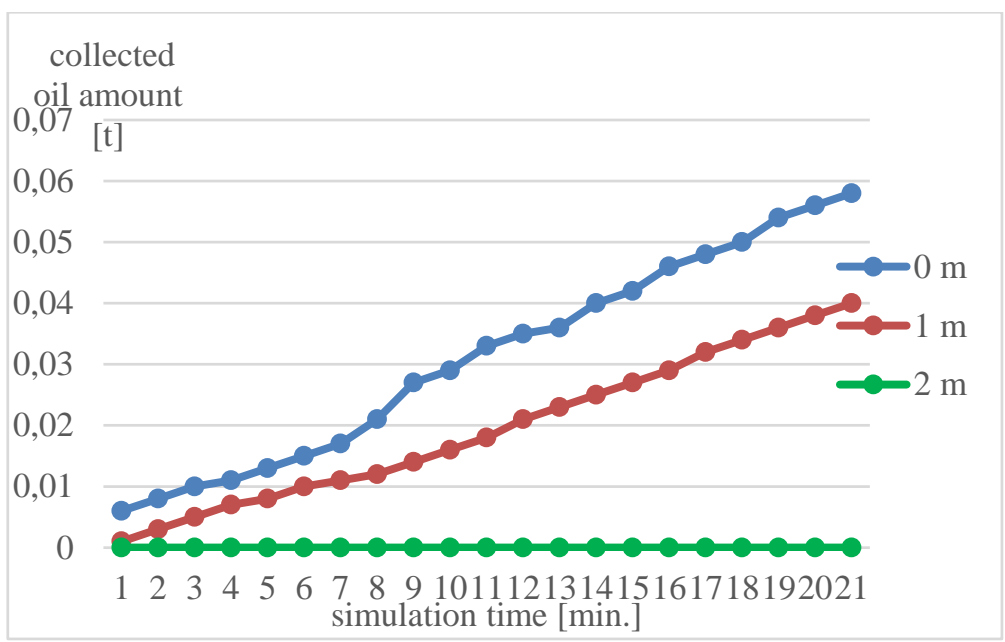

Fig. 4. Amount of collected light crude (Bent Horn) at various wave heights

For Arabian medium crude oil the recorded efficiency factors were 0.026 and 0.018 , respectively, for wave heights $0 \mathrm{~m}$ and $1 \mathrm{~m}$, which resulted in a very small amount of oil collected, only 0.565 and $0.558 \mathrm{t}$ in a single passage through an oil slick.

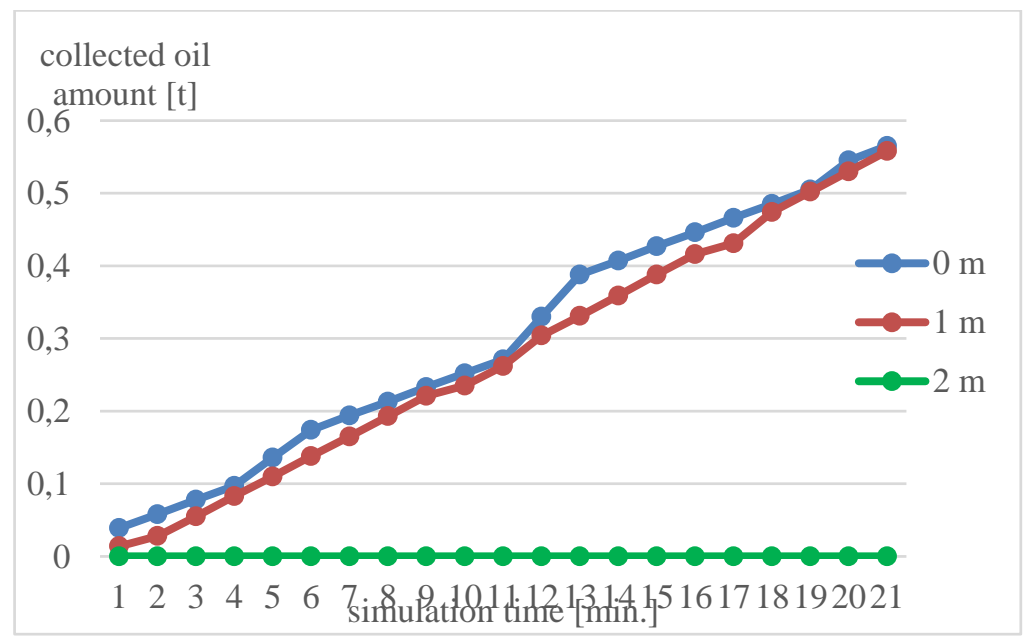

Fig. 5. Amount of collected Arabian medium oil at various wave heights

In the same experiment, the efficiency factor for Belridge heavy oil stood at 0.571 and 0.408 for respective wave heights of $0 \mathrm{~m}$ and $1 \mathrm{~m}$, which resulted in a very large amount of collected oil, over 11 and $8 \mathrm{t}$ in a single passage through an oil slick. 


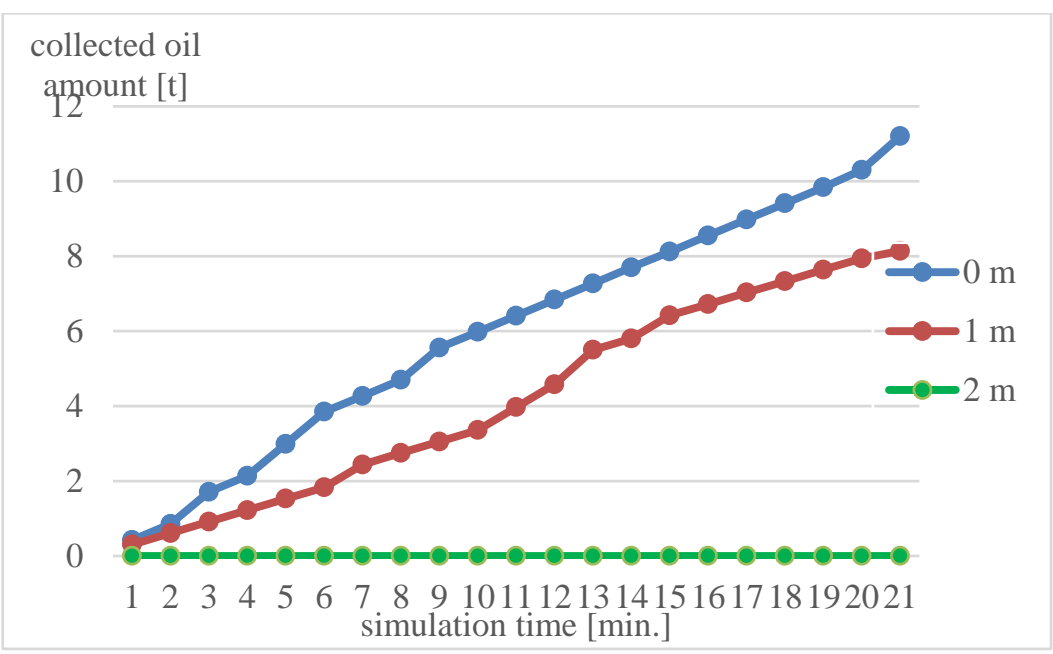

Fig. 6. Amount of collected Belridge heavy oil at various wave heights

Analysing these figures one can easily see that the wave height was important in the experiment, because for all three grades of oil, the wave height of $2 \mathrm{~m}$ made oil skimming and recovery ineffective. In addition to the weather conditions, oil density and viscosity affected the amount of oil collected in the simulation. Oil recovery clearly depended on the cSt value.

Oil viscosity is a major factor restricting the performance of recovery equipment. Oils with a high pour point, including some heavy crude oils and fuel oils generally do not flow easily. If the ambient temperature is lower than the pour point, the oil is in semi-solid state, and will therefore be difficult to recover, because it will not readily flow towards the skimmer [ITOPF 2012].

Mechanical action of water masses promotes the process of making oil-in-water emulsion, or emulsification. The rougher the surface of water is, the less time it takes to create emulsion. Oil-in-water emulsion may contain from 20 to $70 \%$ of oil. Oil emulsion is a very serious problem for teams eliminating the effects of oil spill. [Bądkowski, 1985]. Oil spilled as a thin film (light oil) gets oxidized to a larger degree than oil forming a thick layer or emulsifying.

The experiment showed that weather conditions were of great importance for oil collection efficiency. Wave height limited the ability to collect spilled oil: the higher the wave, the lower the amount of oil recovered. It turned out that two-metre waves caused the spill recovery to be ineffective. 
The problems arising from the increasing viscosity of the oil over time due to weather conditions necessitate re-evaluation of response strategies, including the use of the most applicable skimmer and pumping arrangement. For example, oleophilic skimmers may be able to operate efficiently in oil that has been freshly spilled and has not undergone significant weathering [ITOPF 2012].

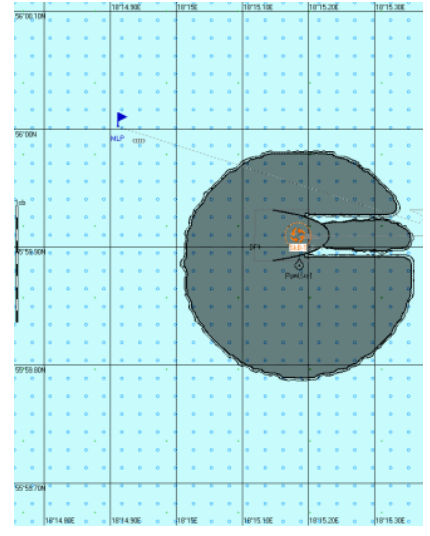

Bent Horn

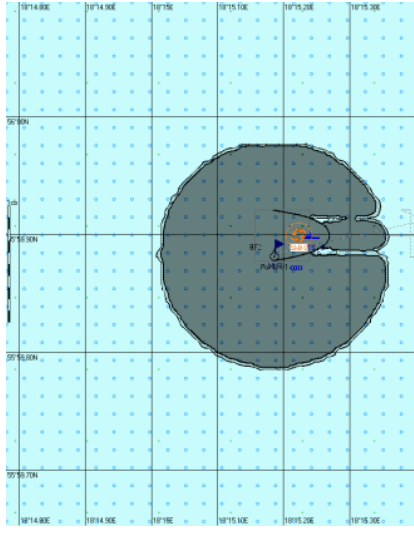

Arabian medium

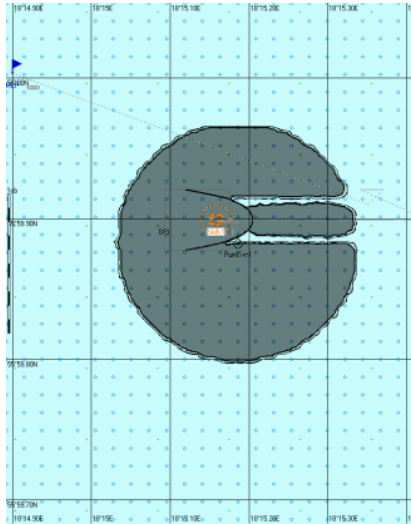

Belridge heavy

Fig. 7. Recovering spills of various oil types at wave height $0 \mathrm{~m}$

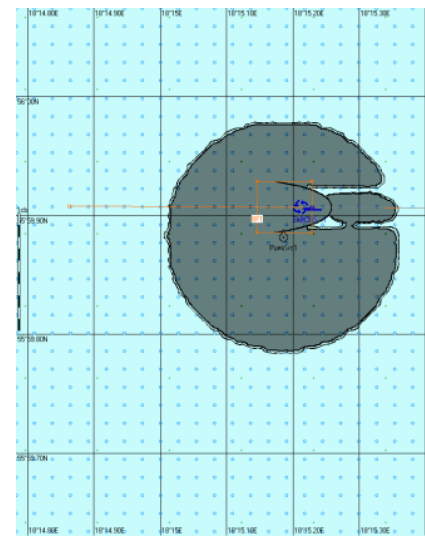

Bent Horn

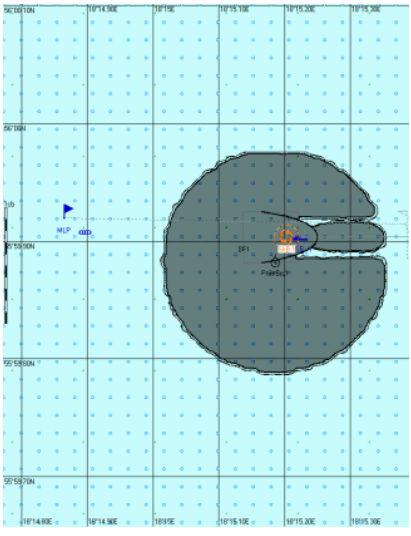

Arabian medium

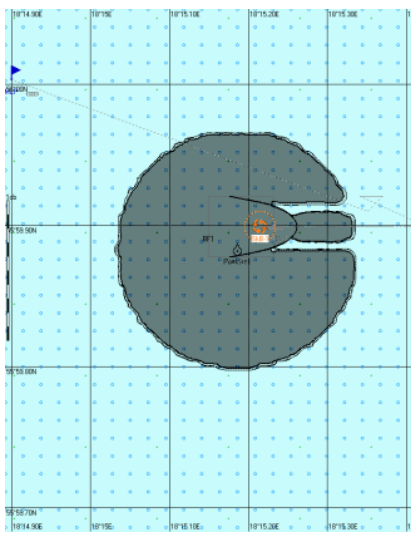

Belridge heavy

Fig. 8. Recovering spills of various oil types at wave height $1 \mathrm{~m}$ 


\section{CONCLUSIONS}

The simulations showed a significant influence of the grade of oil on the efficiency of oil spill recovery from the surface of the sea. Generally, the lighter the oil is, the recovery is less efficient due to oil dispersion and oxidation. Heavy oil forms a thick layer on the surface of the water, can undergo emulsification, and oxidizes slower. These factors make oil collection more efficient. The experiment demonstrated the impact of meteorological conditions on oil collection efficiency. With wave heights of 0 and $1 \mathrm{~m}$ the oil recovery using a belt skimmer was effective, while wave height of $2 \mathrm{~m}$ prevented the removal of petroleum pollutants from the water surface regardless of oil grade.

\section{REFERENCES}

[1] Bądkowski A., Oil spills at sea. Reasons, prevention, detection, combat, greatest disasters [in Polish], Publ. Wydawnictwo Morskie, Gdańsk 1985.

[2] Burungale S., Kamble M., Deokar A., Kamble S., Kuber K. H., Oil Skimmer Mechanism in Sugar Factory, 'International Journal of Mechanical and Industrial Technology' October 2015 - March 2016, Vol. 3, Issue 2, pp. 174-176, [online], www.researchpublish.com [access 23.09.2017].

[3] Fabisiak J., Ecological threats of Baltic Connected With Chemical Pollutions Hydrocarbons [in Polish], 'Scientific Journal of Polish Naval Academy', 2008, No. 3 (174).

[4] Górtowski P., Łazuga K., The Influence of the Oil-spills on the Efficiency of SAR Action [in Polish], 'Górnictwo i Geoinżynieria', 2011, No. 4/1.

[5] Hammoud A., Khalil M. F., Hydrodynamic characteristics of belt skimmer for removing oils, Proc. 1st Conference on Oil Spills in the Mediterranean and Black Sea Regions, Istanbul 2000, pp. 125-135.

[6] ITOPF 2012, Use of skimmers in oil pollution response, Technical information paper.

[7] Kassab S. Z., Empirical Correlations for the Performance of Belt Skimmer Operating under Environmental Dynamic Conditions, 'International Journal of Water Resources and Environmental Engineering', 2010, Vol. 2(5), pp. 121-129, [online], http://www.academicjournals.org/IJWREE, (C2010 Academic Journals [access 20.09.2017].

[8] PISCES II (version 2.93), Transas Ltd., 2008.

[9] Shoier A. Effect of Different Parameters on Belt Skimmer Characteristics, M. Sc. Thesis, Alexandria University, 1998. 
Received September 2016

Reviewed October 2017

Published 09.01.2018

\section{DOROTA JARZĄBEK}

Maritime University of Szczecin

Wały Chrobrego 1-2 Str., 70-500 Szczecin, Poland

e-mail: d.jarzabek@am.szczecin.pl

\section{WIESLAW JUSZKIEWICZ}

Maritime University of Szczecin

Wały Chrobrego 1-2 Str., 70-500 Szczecin, Poland

e-mail:w.juszkiewicz@am.szczecin.pl

\section{STRESZCZENIE}

Możliwość wykorzystania symulacji komputerowej do prognozowania zachowania się rozlewów olejowych na morzu umożliwia lepsze wykorzystanie posiadanych sił i środków służących do ich zwalczania. Zastosowanie odpowiednio dobranego do warunków sprzętu jest istotne $\mathrm{z}$ punktu widzenia efektywności prowadzonej akcji. W związku z tym podjęto próbę weryfikacji wpływu warunków meteorologicznych na skuteczność usuwania powstałego zanieczyszczenia olejowego. Zasymulowano rozlewy trzech typów ropy naftowej. Eksperyment przeprowadzono w symulatorze rozlewów olejowych PISCES II. Przeprowadzone symulacje wykazały istotny wpływ rodzaju ropy na skuteczność akcji usuwania zanieczyszczeń z powierzchni morza, im lżejsza ropa tym zbieranie przebiega w mniejszym stopniu z uwagi na jej rozpraszanie i utlenianie. Ropa ciężka tworzy grubą warstwę na powierzchni wody, może ulegać emulsyfikacji, wolniej ulega procesom utleniania, co prowadzi do efektywnego jej zbierania. Doświadczenie ukazało wpływ warunków meteorologicznych na sprawność zbierania ropy, przy wysokości fali 0 i $1 \mathrm{~m}$ usuwanie ropy za pomocą skimmera pasowego było skuteczne, a fala o wysokości $2 \mathrm{~m}$ uniemożliwiała usuwanie zanieczyszczeń ropopochodnych z powierzchni wody bez względu na jej rodzaj. 